\title{
Efficacy of Modified Atmosphere Packaging to Control Sitophilus spp. in Organic Maize Grain
}

\author{
Marcelo De Carli ${ }^{1}$, Bruna Bresolin ${ }^{1}$, Caciano Pelayo Zapata Noreña ${ }^{1 *}$, Irineu Lorini ${ }^{2}$ and \\ Adriano Brandelli ${ }^{1}$ \\ ${ }^{I}$ Instituto de Ciência e Tecnologia de Alimentos; Universidade Federal do Rio Grande do Sul; Av. Bento Gonçalves, \\ 9500; 91501-970; Porto Alegre - RS - Brasil. ${ }^{2}$ Empresa Brasileira de Pesquisa Agropecuária; Rodovia BR 285; Km \\ 174; 99001-970; Passo Fundo - RS - Brasil.
}

\begin{abstract}
The effect of modified atmosphere packaging on the mortality of Sitophilus spp. in organic maize grain was studied. Maize grains were packed with five different atmospheres consisting of $20 \% \mathrm{O}_{2}$, or 20, 40, 60, $80 \% \mathrm{CO}_{2}$ with remaining $\mathrm{N}_{2}$. The packages were stored for 30 days at $26^{\circ} \mathrm{C} . \mathrm{CO}_{2}$ and $\mathrm{O}_{2}$ concentrations were monitored inside the packages during the storage. The moisture content, titratable acidity and $\mathrm{pH}$ were analysed on the first and thirtieth day. At 5, 15 and 30 days of storage no significant differences were observed in the percentages of dead insects when $\mathrm{CO}_{2}$ was used. The results of progeny indicated that from the fifth day the number of emerging insects was low at 20, 60 and $80 \% \mathrm{CO}_{2}$. Complete inhibition of the insects was achieved with 30 days of exposure in $\mathrm{CO}_{2}$ atmospheres.
\end{abstract}

Key words: Carbon dioxide; Modified atmosphere; Insect mortality.

\section{INTRODUCTION}

The explosion of human population in developing countries is creating an unprecedented demand for greater production of food grains (MorenoMartinez et al., 2000). The postharvest losses due to infestation by insect pests have required the use of diverse procedures for the control of the arthropods (Gbaye and Odeyemi, 2005). Sitophillus spp. is a major pest of stored maize grain in Brazil and its control must be made efficiently to reduce the loss in grain.

In the recent past, the preservation of cereals and other durable agricultural products during the storage has relied heavily upon the insecticides to control the storage pests. However, the present trend is towards alternative non-toxic control methods that pose no threat to the health of operator or consumer, and which are environmentally friendly (Donahaye et al., 1996). Developing countries have resorted primarily to the use of insecticides (Moreno-Martinez et al., 2000) and most of the contact insecticides have been restricted for use on food materials (Shunmugam et al., 2005). Along with preventive practices, the farmers rely mostly on chemical control of stored products pests. However, this can be potentially harmful to human health in the form of chemical residues (Shunmugam et al., 2005).

The consumers today expect the food products that are pesticide free or with lower levels of residues (Conyers and Bell, 2007). In addition, pressure

*Author for correspondence: czapatan@ufrgs.br 
from the international consumer groups to reduce the chemicals used in food products makes a nonchemical insect control practice highly desirable (Mitcham et al., 2006). It is demanding to develop the alternative methods that are economically feasible and ecologically adjusted to control the storage grain insects and fungi (Moreno-Martinez et al., 2000).

Aeration systems to cool the bulk grains and thereby prevent insect development are being widely used even in warm climates but are only applicable for the bulk grains. Other non-residual treatments such as mechanical impact, irradiation, biological control or heating are suitable for highquality commodities or niche situations (Donahaye, 2000). $\mathrm{CO}_{2}$ has considerable attraction as a means of disinfecting foodstuff in general and stored durable products in particular (Annis and Morton, 1997). This technology can be used in hermetic storage. The use of controlled atmospheres using either $\mathrm{N}_{2}$ or $\mathrm{CO}_{2}$ closely depends on well-sealed storage structures, which are rarely available in rigid silos, but easily obtainable with flexible plastic liners (Donahaye, 2000). Donahaye and Navarro (2000) reported the use of modified atmospheres (MA) as a non-toxic and environmentally benign alternative to fumigation for the control of insects in stored products. MA has been used in the agricultural and food industries for the protection and preservation of raw materials from harvest to the finished product (Conyers and Bell, 2007).

Disinfestation of stored grain using MA involves the alteration of the natural storage gases such as $\mathrm{CO}_{2}, \mathrm{O}_{2}$ and $\mathrm{N}_{2}$ to render the atmosphere in the stores lethal to pests (Jayas and Jeyamkondan, 2002). As a method for insect control in bulk commodities, $\mathrm{MA}$ systems increased $\mathrm{CO}_{2}$ or decreased $\mathrm{O}_{2}$ atmospheres, or a combination of both (Bell, 2000; Donahaye and Navarro, 2000). MA may adversely affect the arthropods both through creation of a hypoxic (low $\mathrm{O}_{2}$ ) environment, as well as from direct physiological effects of the gases (Held et al., 2001).

The maize is an agricultural product widely distributed in Brazil, and is commercialized natural form or with minimal processing to reduce the cost (Biazus et al., 2009). High value commodities, such as organic maize grain may be adapted for MA in flexible plastic containers for transporting overseas to extend its shelf life and to kill the insects. The aim of this study was to evaluate the effect of the atmosphere modified packaging on the mortality of Sitophilus spp. in organic maize grain.

\section{MATERIALS AND METHODS}

\section{Samples}

The organic maize grains (variety Fundacep 35) were supplied by Coperfamília (Tenente Portela, Rio Grande do Sul State, Brazil). The samples were cleaned, dried and kept in the fridge at $8^{\circ} \mathrm{C}$.

\section{Insect}

Unsexed adults of Sitophilus spp. were obtained from the Laboratory of Brazilian Agricultural Research Corporation (Embrapa, Passo Fundo, Brazil). In order to obtain an insect population of know age, 550 adult weevils (both sexes) were transferred to 21 plastic jar containing $1 \mathrm{~kg}$ of maize grain. These were then covered with a lid of metal mesh. This procedure was repeated four times. The jars were kept at $26^{\circ} \mathrm{C}, 55 \% \mathrm{RH}$, in a 12-12 h light and dark photoperiod. After 15 days, all the insects were removed and the maize grains were again kept in the same condition for 56 days. After this period, the adults which emerged from these cultures were used in the experiments.

\section{Experimental procedures}

Fifty insects were placed in a plastic flask containing $250 \mathrm{~g}$ of maize grains and kept for 40 days as described above. After this period, all the contents (insect and maize) were transferred to the bags with barrier properties (Sealed Air CRYOVAC). The air was evacuated and a food grade gas mixture (White Martins, Porto Alegre, Brazil) was introduced into the package before heat-sealing using a vacuum sealer (Selovac, model 200). The experiments were conducted for various modified atmosphere packaging: $20 \%$ (v/v) $\mathrm{O}_{2}, \quad 20,40,60,80 \% \quad(\mathrm{v} / \mathrm{v}) \quad \mathrm{CO}_{2}$ with remaining $\mathrm{N}_{2}$ and 30 days exposure at $26^{\circ} \mathrm{C}$.

After the exposure, the packages were opened and all the materials were placed on a table in order to register the number of insects. Dead insects were recognized by their lack of movement despite a range of stimuli (prodding, subjecting to small breeze and leaving undisturbed). Special care was taken to ensure that death had really occurred (Annis and Morton, 1997). If they moved, they were scored as live. Recording of the dead insects were realized at $1,2,3,4,5,15$ and 30 days 
exposure to modified atmosphere packaging at $26^{\circ} \mathrm{C}$.

After registering the number of dead insects and removing the live ones, the grains were returned to the jars and kept again at $26^{\circ} \mathrm{C}, 55 \% \mathrm{RH}$ for 45 days to observe the possible emergence of insects. After this period, the emergence of adult insects from any progeny was recorded.

\section{Headspace gas composition}

The $\mathrm{CO}_{2}$ and $\mathrm{O}_{2}$ concentrations were measured using a gas analyzer (MOCON, model Pac Check 65). To avoid the modifications in the headspace gas composition due to gas sampling, each package was used only for a single determination of the headspace gas composition (Del Nobile et al., 2006). The $\mathrm{O}_{2}$ and $\mathrm{CO}_{2}$ concentrations in the headspace of packages filled with the maize grains and the insects were measured after 1, 2, 3, 4, 5, 15 and 30 days exposure to modified atmosphere packaging at $26^{\circ} \mathrm{C}$.

\section{Moisture, titratable acidity and $\mathbf{p H}$}

The moisture content, titratable acidity and $\mathrm{pH}$ values were determined after one and 30 days exposure of the grains and insects in AM packaging according to AOAC methods 925.10, 942.15 and 943.02, respectively (AOAC, 1990).

\section{Statistical analysis}

A $5 \times 7$ factorial design was planned in order to study the influence of $\mathrm{CO}_{2}$ concentration and storage period on the mortality insects. Tukey's test was used to determine the statistically significant differences between the treatment means at $p=0.05$. The experiments were repeated three times. Statistical analysis was completed using the SAS software (SAS Institute Inc., Cary, N.C. USA).

\section{RESULTS}

\section{Physico-chemical analysis}

The maize grain with moisture content of $10.43 \%$ (m.c.), $3.52 \mathrm{mg} \mathrm{NaOH} / 100 \mathrm{~g}$ of acidity and $\mathrm{pH}$ of 6.25 was used to the test. The results of moisture content, acidity titratable and $\mathrm{pH}$ are summarized in Table 1. The moisture content significantly increased $(p<0.05)$ with exposure time at $20 \% \mathrm{O}_{2}$, 20 and $40 \% \mathrm{CO}_{2}$, but not when 60 or $80 \% \mathrm{CO}_{2}$ was used $(p>0.05)$. The highest moisture content on the thirtieth day was observed at $40 \% \mathrm{CO}_{2}$.

Titratable acidity was almost constant in the time studied, except at 20 and $80 \% \mathrm{CO}_{2}$ (Table 1). In addiction, on the thirtieth day, no differences $(p>0.05)$ were found among the different atmospheres tested. No significant changes in the $\mathrm{pH}$ values were observed at 20,40,60 and $80 \%$ $\mathrm{CO}_{2}$ within the exposure time. In addition, on the thirtieth day, no significant changes in the $\mathrm{pH}$ values were found at different atmospheres.

Table 1 - Summary of means of moisture content, titratable acidity and $\mathrm{pH}$ values at different conditions of AM packaging.

\begin{tabular}{|c|c|c|c|c|c|c|}
\hline \multirow[b]{3}{*}{ Initial atmosphere } & \multicolumn{6}{|c|}{ Time (days) } \\
\hline & \multicolumn{2}{|c|}{ Moisture content \% } & \multicolumn{2}{|c|}{ Acidity mg 'NaOH/100g } & \multicolumn{2}{|c|}{$\mathbf{p H}$} \\
\hline & 1 & 30 & 1 & 30 & 1 & 30 \\
\hline $20 \% \mathrm{O}_{2}$ & $9.92 \pm 0.26$ & $\underset{b,(a, b)}{10.79+0.24}$ & $\underset{\mathrm{a},(\mathrm{a})}{3.50 \pm 0.22}$ & $\underset{\mathrm{a},(\mathrm{a})}{3.22+0.40}$ & $\underset{\mathrm{a},(\mathrm{c})}{6.40 \pm 0.04}$ & $6.54+\frac{0.06}{\mathrm{~b},(\mathrm{a})}$ \\
\hline $20 \% \mathrm{CO}_{2}$ & $\underset{\mathrm{a}, \overline{(\mathrm{a})}}{10.21+0.22}$ & $10.85+\underset{b,(a, b)}{+0.10}$ & $\underset{\mathrm{a},(\mathrm{a})}{3.48+0.22}$ & $\underset{\mathrm{b},(\mathrm{a})}{2.90+0.32}$ & $\underset{\mathrm{a}, \overline{(\mathrm{b}, \mathrm{c})}}{6.52+0.05}$ & $\underset{\mathrm{a},(\mathrm{a})}{6.55+0.06}$ \\
\hline $40 \% \mathrm{CO}_{2}$ & $\underset{\mathrm{a},(\mathrm{a})}{9.71+0.48}$ & $\underset{\mathrm{b},(\mathrm{a})}{11.03+0.23}$ & $\underset{\mathrm{a},(\mathrm{b})}{2.70 \pm 0.25}$ & $\underset{\mathrm{a},(\mathrm{a})}{2.98+0.30}$ & $\underset{\mathrm{a},(\mathrm{a}, \mathrm{b})}{6.59+0.03}$ & $\underset{\mathrm{a},(\mathrm{a})}{6.56+0.01}$ \\
\hline $60 \% \mathrm{CO}_{2}$ & $\underset{\mathrm{a}, \frac{(\mathrm{a})}{10.21}}{\cos }$ & $\underset{\mathrm{a},(\mathrm{b})}{10.52+0.27}$ & $\underset{\mathrm{a},(\mathrm{b})}{2.80 \pm 0.16}$ & $\underset{\mathrm{a},(\mathrm{a})}{2.86+0.38}$ & $\underset{\mathrm{a},(\mathrm{a})}{6.66+0.10}$ & $\underset{\mathrm{a},(\mathrm{a})}{6.58+0.02}$ \\
\hline $80 \% \mathrm{CO}_{2}$ & $\underset{\mathrm{a}, \overline{(\mathrm{a})}}{10.15+0.74}$ & $\begin{array}{c}10.45+0.35 \\
\mathrm{a},(\mathrm{b})\end{array}$ & $\underset{\mathrm{a},(\mathrm{b})}{2.64+0.23}$ & $\underset{b,(a)}{3.08+0.15}$ & $\underset{\mathrm{a}, \overline{(\mathrm{a}, \mathrm{b})}}{6.59 \pm 0.06}$ & $\underset{\mathrm{a},(\mathrm{a})}{6.56+0.02}$ \\
\hline
\end{tabular}

Means followed by different letters indicate significant differences $(p<0.05)$ between *days or ()$^{*}$ between concentrations. 


\section{Headspace atmosphere}

The evolution of internal $\mathrm{CO}_{2}$ and $\mathrm{O}_{2}$ concentrations with exposure time can be observed in Figures 1 and 2 respectively. At $20 \% \mathrm{O}_{2}$, internal levels of $\mathrm{CO}_{2}$ increased while $\mathrm{O}_{2}$ concentrations rapidly decreased. After the fifth day, the levels of $\mathrm{CO}_{2}$ started to decrease. When $\mathrm{CO}_{2}$ was used, the internal $\mathrm{CO}_{2}$ concentrations slightly decreased from the day 3 (Fig. 1). After the fifteenth day, $\mathrm{CO}_{2}$ achieved a steady-state condition. The initial internal $\mathrm{O}_{2}$ concentration was around $0.8 \% \mathrm{O}_{2}$, consequence to vacuum produced before inputting $\mathrm{CO}_{2}$ into the package. On the first day the $\mathrm{O}_{2}$ concentration decreased to $0.14 \%$. However, $\mathrm{O}_{2}$ levels slightly increased after the fifth day. On the thirtieth day, the $\mathrm{O}_{2}$ levels significantly increased $(p<0.05)$, except at $20 \%$ $\mathrm{CO}_{2}$. This could be due to the package used, which was a $\mathrm{O}_{2}$ low permeability film.

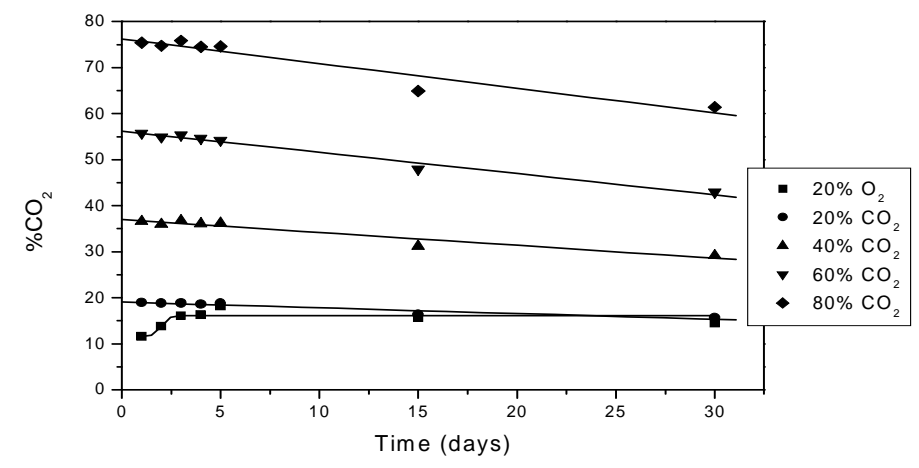

Figure 1 - Evolution of the internal $\mathrm{CO}_{2}$ concentration inside of the package at different conditions of AM packaging.

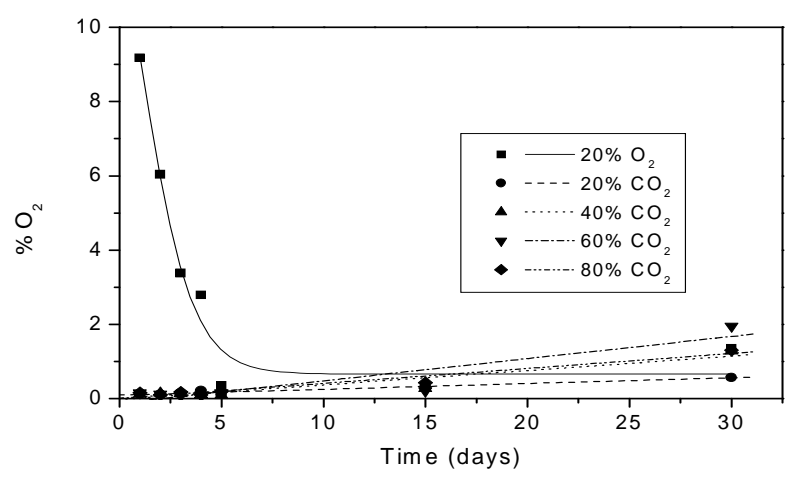

Figure 2 - Evolution of the internal $\mathrm{O}_{2}$ concentration inside of the package at different conditions of AM packaging.

\section{Effect on adult insects}

The percentages of mortality under different MA conditions are presented in the Table 2. At $20 \%$ $\mathrm{O}_{2}$, the mortality from the second day was significantly lower when compared with any $\mathrm{CO}_{2}$ concentration. During all the exposure times studied at $20 \% \mathrm{O}_{2}$, the percentages of dead insects were lesser than $9 \%$. When $\mathrm{CO}_{2}$ was used, from the fifth day, the higher percentages of insect mortalities were obtained and no differences $(p>0.05)$ in the percentages of dead insects were observed at 5,15 and 30 days of exposure.

\section{Effect on progeny}

It was observed that under $20 \% \mathrm{O}_{2}$, the emergence of new insects was not repressed in the periods 
less than 30 days (Fig. 3). The highest amount of adult emergence from the progeny was observed at $20 \% \mathrm{CO}_{2}$ and two days of exposure. The insect emergences began to decrease from the fifth day, being the number of live insects lower than three using 20, 60 and $80 \% \mathrm{CO}_{2}$. On the fifteenth day, there were less than one insect at 20,40,60 and $80 \% \mathrm{CO}_{2}$. On the thirtieth day, no live insects were found at 20, 40, 60 and $80 \% \mathrm{CO}_{2}$ (Fig. 3).

\section{DISCUSSION}

In the experiments conducted in the absence of insects, no significant changes were found in the moisture content between the first and the thirtieth day. Moreno-Martinez et al. (2000) found that the moisture content of the maize grain stored under hermetic conditions remained almost the same as the initial values. When the tests were conducted in the presence of insects, a significant increase $(p<0.05)$ of moisture content at $20 \% \mathrm{O}_{2}, 20$ and $40 \% \quad \mathrm{CO}_{2}$ was observed. The increase in the moisture content in the grains was usually a result the metabolic activity of insects. Caneppele et al. (2003) found that the infestation of stored corn with the adults of $S$. zeamais elevated the seed moisture content, which favored the proliferation of molds by the ninetieth day. The grain stored with high moisture content is subjected to high losses caused by the attack of the insects and fungi (Vásquez-Castro et al., 2008).

Table 2 - Means (\%) of mortality in adult insects at different conditions of AM packaging.

\begin{tabular}{|c|c|c|c|c|c|c|c|}
\hline \multirow{2}{*}{$\begin{array}{c}\text { Initial } \\
\text { atmosphere }\end{array}$} & \multicolumn{7}{|c|}{ Days } \\
\hline & 1 & 2 & 3 & 4 & 5 & 15 & 30 \\
\hline $20 \% \mathrm{O}_{2}$ & $\underset{\mathrm{a},(\mathrm{b})}{6.7 \pm 2.0}$ & $3.3 \pm 1.1$ & $\underset{\substack{a, b,(c) \\
4.0 \pm 2.0}}{4}$ & $\underset{\mathrm{a}, \mathrm{b}, \mathrm{b}, \mathrm{b})}{6.0 \pm 2.0}$ & $\begin{array}{c}2.7 \pm 0.6 \\
b,(b)\end{array}$ & 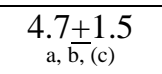 & $8.7 \pm 3.2$ \\
\hline $20 \% \mathrm{CO}_{2}$ & $6.7 \pm+3.0$ & $\underset{\mathrm{d},(\bar{b})}{14.7+6.4}$ & $\underset{\mathrm{c},(\bar{a}, \mathrm{~b})}{40.0+4.0}$ & $\underset{\mathrm{b},(\mathrm{a})}{74.7 \pm 9.0}$ & $\underset{\mathrm{a},(\mathrm{a})}{98.7+1.1}$ & $\underset{\mathrm{a},(\mathrm{a})}{97.3+2.7}$ & $\underset{\text { a, }(\bar{a})}{98.0 \pm 2.0}$ \\
\hline $40 \% \mathrm{CO}_{2}$ & $\underset{\mathrm{d},(\mathrm{a})}{22.0 \pm 7.2}$ & $23.3 \pm 1.1$ & $\underset{\mathrm{c},(\mathrm{b})}{38.7+2.3}$ & $\underset{\mathrm{b},(\mathrm{a})}{84+2.0}$ & $\underset{\mathrm{a},(\mathrm{a})}{100.0 \pm 0}$ & $\underset{\mathrm{a},(\mathrm{a}, \mathrm{b})}{96.0 \pm 2.0}$ & $\underset{\mathrm{a},(\mathrm{a})}{98.0+2.0}$ \\
\hline $60 \% \mathrm{CO}_{2}$ & $\underset{\mathrm{d},(\mathrm{a})}{16.0 \pm 3.8}$ & $\underset{\mathrm{c}, \mathrm{d},(\mathrm{a})}{28.0+5.3}$ & $\underset{\mathrm{c},(\mathrm{a}, \mathrm{b})}{47.3}$ & $\underset{\mathrm{b},(\mathrm{a})}{80.7+5.0}$ & $\underset{\mathrm{a},(\mathrm{a})}{98.0+2.0}$ & $\underset{\mathrm{a},(\mathrm{a})}{98.0+2.0}$ & $\underset{\mathrm{a}, \mathrm{b}, \text {, (a) }}{85.3} \underset{10.7}{ }$ \\
\hline $80 \% \mathrm{CO}_{2}$ & $\underset{\mathrm{e},(\overline{\mathrm{a}, \mathrm{b})}}{10.7+4.0}$ & 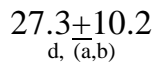 & $\begin{array}{c}52.7+\frac{ \pm}{\mathrm{c},(\mathrm{a})} \\
\end{array}$ & $\underset{a, b,(a)}{77.3 \pm 8.3}$ & $\underset{\mathrm{a}, \bar{b},(\mathrm{a})}{92 \pm 7.8}$ & $\underset{\mathrm{a}, \mathrm{b},(\mathrm{b})}{82.7 \pm 12.5}$ & $\underset{\mathrm{a}, \overline{(\mathrm{a})}}{98.0+2.0}$ \\
\hline
\end{tabular}

Means followed by different letters indicate significant differences $(p<0.05)$ between $*$ days or ()$^{*}$ between concentrations.

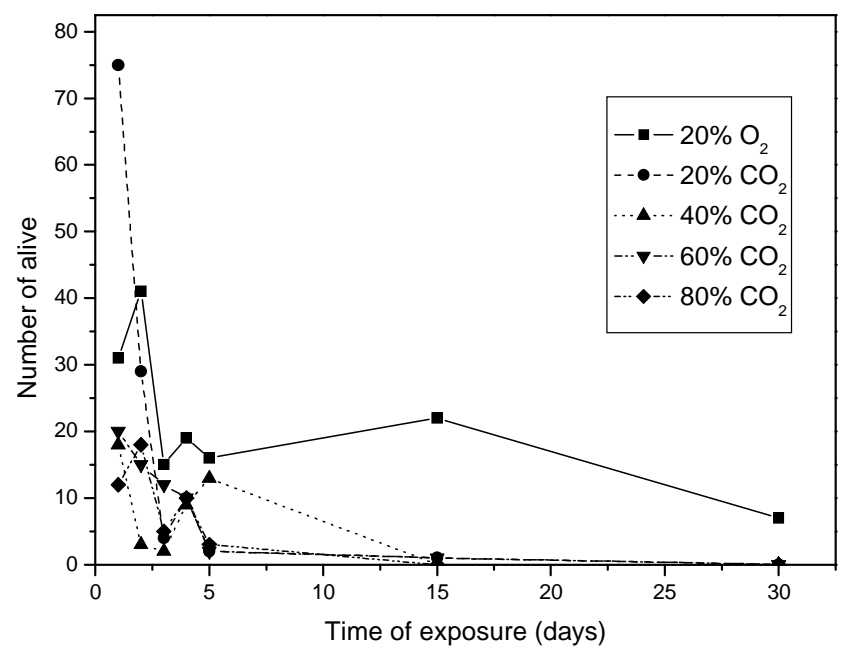

Figure 3 - Adult emergence from any progeny at different conditions of AM packaging. 
However, at 60 and $80 \% \mathrm{CO}_{2}$ changes in moisture were not significant $(p \geq 0.05)$. This behavior was due to the diminished respiration rates of both the insects and grains when they were in modified atmosphere or in low $\mathrm{O}_{2}$ concentrations. In addition, low levels of moisture also decreases the respiratory rate of maize grain.

No significant changes in $\mathrm{pH}$ were observed when the atmosphere with $20 \mathrm{CO}_{2}$ was used, as well as to acidity at 40 and $60 \% \mathrm{CO}_{2}$. Rehman et al. (2002) reported that there was no change in $\mathrm{pH}$ and titrable acidity of maize grains kept at $10^{\circ} \mathrm{C}$ for six months storage. However, they observed a decrease in $\mathrm{pH}$ and increase in acidity after 30 days of storage at 25 and $45^{\circ} \mathrm{C}$.

It was observed that in the atmosphere with $20 \%$ $\mathrm{O}_{2}$, there was a high consumption of $\mathrm{O}_{2}$ in the first five days, whereas $\mathrm{CO}_{2}$ increased to $18.1 \%$. This behavior was associated with the respiration of insect, grain and microorganisms in the package, a physiological process that occurred involving the $\mathrm{O}_{2}$ and $\mathrm{CO}_{2}$. Insects are the main consumers of $\mathrm{O}_{2}$, followed by fungi and grains. Thus, insects and fungi deplete the $\mathrm{O}_{2}$, creating a most unfavorable atmosphere for themselves (Moreno-Martinez et al., 2000).

When the experiments were conducted with $\mathrm{CO}_{2}$, the $\mathrm{O}_{2}$ concentration achieved was lower than $0.5 \%$ until the fifteenth day. After this period, $\mathrm{O}_{2}$ level increased significantly to values up to $2 \%$, except for $20 \% \mathrm{CO}_{2}$. ANOVA revealed that $\mathrm{CO}_{2}$ concentration $(p<0.05)$, time of exposure $(p<0.05)$, and their interaction $(p<0.05)$ were significant factors affecting the $\mathrm{CO}_{2}$ concentration. Figure 1 depicted that the $\mathrm{CO}_{2}$ concentration decreased with the time and initial levels of $\mathrm{CO}_{2}$. On the contrary, the concentration of $\mathrm{O}_{2}$ was independent of initial concentration of $\mathrm{CO}_{2}$ and their concentration began to increase slowly after the fiftieth day (Fig. 1).

The consumption and production of $\mathrm{O}_{2}$ and $\mathrm{CO}_{2}$ by vegetable tissues are metabolically interrelated, making difficult to study the effect of one gas independent the other. The uncontrolled nature of the atmosphere in the package and the time interval required to reach the equilibrium are additional factors that complicate the interpretation of the results (Saltveit, 2003). Besides, there is the transfer of gases through the packaging, leading to an atmosphere richer in $\mathrm{CO}_{2}$ and poorer in $\mathrm{O}_{2}$ (Fonseca et al., 2002).

The mortality observed for Sitophilus spp. when high $\mathrm{CO}_{2}$ concentrations were used could be associated with either $\mathrm{O}_{2}$ depletion or $\mathrm{CO}_{2}$ toxicity or the interaction of both (Annis and Morton, 1997). However, the natural permeability of cellular membranes appeared to be an important protection mechanism for the survival of arthropods under low $\mathrm{O}_{2}$ or high $\mathrm{CO}_{2}$ atmospheres (Mitcham et al., 2006). Hoback and Stanley (2001) described that arthropods were hypoxia-tolerant organisms, although their mortality increased with the lower $\mathrm{O}_{2}$ concentrations. Mitcham et al. (2006) also showed that in the case of using controlled atmosphere, the insecticidal conditions generally contained concentration higher than $20 \% \quad \mathrm{CO}_{2}$ and/or lower than $1 \% \quad \mathrm{O}_{2}$, depending on the temperature, with the remaining of the atmosphere composed of $\mathrm{N}_{2}$ gas.

ANOVA showed that time, $\mathrm{CO}_{2}$ concentration, and their interaction $(p<0.05)$ were significant factors affecting Sitophilus mortality, indicating that these two factors acted together on the mortality of insects. Similar behavior was observed by Annis and Morton (1997), who reported that the use of time-concentration relationship was not directly applicable to explain the effects of $\mathrm{CO}_{2}$ on $S$. oryzae because of the interdependent effects of lowered $\mathrm{O}_{2}$ and increased $\mathrm{CO}_{2}$ concentrations. In addition, there was a particular time interval for each species after that an irreversible damage was done to their metabolism (Conyers and Bell, 1996).

In this work, it was shown that after five days of exposure in any initial $\mathrm{CO}_{2}$ concentration studied, the number of insects diminished drastically. In addition to the effect of the concentrations of $\mathrm{CO}_{2}$ and $\mathrm{O}_{2}$ and time, there are other factors that may influence the effect of these atmospheres on the arthropods, such as temperature, grain moisture, insect species and life stage (Pearson and Sorenson, 1970; Mitcham et al., 2006).

In the experiments developed to evaluate the effect on progeny, total inhibition was achieved at 30 days using $\mathrm{CO}_{2}$ atmospheres. This time corresponded to $\mathrm{O}_{2}$ concentrations lower than $2 \%$. Conyers and Bell (2007) mentioned that an increase of $\mathrm{CO}_{2}$ to 10 or $20 \%$, reducing $\mathrm{O}_{2}$ to $5 \%$ was sufficient to eliminate the emergence of Sitophilus granarius at $20^{\circ} \mathrm{C}$, but a few individuals emerged at $25^{\circ} \mathrm{C}$. In addition, $S$. granarius exposed to atmospheres containing 1 to $1.6 \% \mathrm{O}_{2}$ with a balance of $\mathrm{N}_{2}$ at $20^{\circ} \mathrm{C}$ and $70 \% \mathrm{RH}$ were killed within seven days if the atmosphere also contained $10 \%$ or more $\mathrm{CO}_{2}$ (Krishnamurthy et al., 1986). Other studies have shown that the minimum 
concentration of $\mathrm{CO}_{2}$ useful for the complete disinfestation of $S$. oryzae was lower than $40 \%$ but substantially above $20 \% \mathrm{CO}_{2}$ (Annis and Morton, 1997). Arthropod mortality is generally greater in response to elevated $\mathrm{CO}_{2}$ atmospheres when compared with low $\mathrm{O}_{2}$ atmospheres (Mitcham et al., 2006).

This study showed the possibility of using MA packaging in order to protect the maize grains produced organically against insect attack. It was observed that the relationship between the initial $\mathrm{CO}_{2}$ concentration and time was important to achieve the higher percentages of mortality for adult insects. Atmospheres containing higher than $20 \% \mathrm{CO}_{2}$ and lower than $2 \% \mathrm{O}_{2}$ and higher than five days of exposure were necessary to eliminate most adult insects. However a period of 30 days was necessary to achieve the total inhibition of the progeny.

\section{RESUMO}

O efeito da embalagem em atmosferas modificadas sobre os insetos Sitophilus spp. nos grãos de milho orgânico foi estudado. Os grãos de milho foram empacotados em cinco atmosferas iniciais diferentes de $20 \%$ de $\mathrm{O}_{2}$, ou 20,40,60, $80 \%$ de $\mathrm{CO}_{2}$ com balanço de $\mathrm{N}_{2}$. As embalagens foram armazenadas por 30 dias a $26^{\circ} \mathrm{C}$. As concentrações de $\mathrm{CO}_{2}$ e $\mathrm{O}_{2}$ foram monitoradas dentro das embalagens durante o armazenamento. As análises de teor de umidade, acidez e $\mathrm{pH}$ foram também realizados no primeiro e trigésimo dia. Os resultados mostraram que no quinto, décimo quinto e trigésimo dia de estocagem não foram encontrados diferenças significativas nas porcentagens de insetos mortos quando $\mathrm{CO}_{2}$ foi usado. Os resultados relativos à progênie indicaram que no quinto dia o número de insetos emergentes foi menor a 20,60 e $80 \% \mathrm{CO}_{2}$. A completa inibição dos insetos foi atingida com 30 dias de exposição em atmosferas de $\mathrm{CO}_{2}$.

\section{REFERENCES}

Annis, P.C.; Morton, R. (1997), The acute mortality effects of carbon dioxide on various life stages of Sitophilus oryzae. J. Stored Products Res., 33, 115124.
AOAC (1990), Official Methods of Analysis. 13th edn., Washington: Association of Official Analytical Chemists.

Bell, C .H. (2000), Fumigation in the 21st century. Crop Prot., 19, 563-569.

Biazus, J.P.M.; Souza, R.R.; Márquez, R.R.; Franco, T.T.; Santana, J.C.C.; Tambourgi, E.B. (2009), Production and Characterization of Amylases from Zea mays Malt. Braz. arch. biol. technol., 52, 9911000.

Conyers, S.T.; Bell, C.H. (1996), The effect on the mortality of adult Cryptolestes ferrugineus (Stephens) (Coleoptera: Cucujidae), Sitophilus granarius (L.) (Coleoptera: Curculionidae) and Oryzaephilus surinamensis (L.) (Coleoptera: Silvanidae) of interrupting low oxygen exposures with periods of elevated oxygen. J. Stored Products Res., 32, 187194.

Caneppele, M.A.B.; Caneppele, C.; Lázzari, F.A.; Lázzari, S.M.N. (2003), Correlation between the infestation level of Sitophilus zeamais Motschulsky, 1855 (Coleoptera, Curculionidae) and the quality factors of stored corn, Zea mays L. (Poaceae). Rev. Bras. Entomol., 47, 625-630.

Conyers, S.T.; Bell, C.H. (2007), A novel use of modified atmospheres: Storage insect population control. J. Stored Products Res., 43, 367-374.

Del Nobile, M.A.; Baiano, A.; Benedetto, A.; Massignan, L. (2006). Respiration rate of minimally processed lettuce as affected by packaging. J. Food Eng., 74, 60-69

Donahaye, E.J.; Navarro, S.; Rindner, M.; Azrieli, A. (1996), The combined influence of temperature and modified atmospheres on Tribolium castaneum (Herbst) (Coleoptera: Tenebrionidae). J. Stored Products Res., 32, 225-232.

Donahaye, E.J. (2000), Current status of non-residual control methods against stored product pests. Crop Prot., 19, 571-576.

Donahaye, E.J.; Navarro, S. (2000), Comparisons of energy reserves among strains of Tribolium castaneum selected for resistance to hypoxia and hypercarbia, and the unselected strain. J. Stored Products Res., 36, 223-234.

Fonseca, S.C.; Oliveira, F.A.R.; Brecht, J.K. (2002), Modelling respiration rate of fresh fruits and vegetables for modified atmosphere packages: a review. J. Food Eng., 52, 99-119.

Gbaye, O.A.; Odeyemi, O.O. (2005), Evaluation of hypercarbia atmosphere on the mortality of dried-fruit beetle, Carpophilus hemipterus (Linnaeus). J. Food Agr. Environ., 3 (3-4), 43-46.

Held, D.W.; Potter, D.A.; Gates, R.S.; Anderson, R.G. (2001), Modified Atmosphere Treatments as a Potential Disinfestation Technique for Arthropod Pests in Greenhouses. J. Econ. Entomol., 94, 430438. 
Hoback, W.W.; Stanley, D.W. (2001), Insects in hypoxia. J. Insect Physiol., 47, 533-542.

Jayas, D.S.; Jeyamkondan, S. (2002), Modified Atmosphere Storage of Grains Meats Fruits and Vegetables. Biosystems Eng., 82, 235-251.

Krishnamurthy, T.S.; Spratt, E.C.; Bell, C.H. (1986), The toxicity of carbon dioxide to adult beetles in low oxygen atmospheres. J. Stored Products Res., 22, 145-151.

Mitcham, E.; Martin, T.; Zhou, S. (2006), The mode of action of insecticidal controlled atmospheres. Bull. Entomol. Res., 96, 213-222.

Moreno-Martinez, E.; Jiménez, S.; Vázquez, M.E. (2000), Effect of Sitophilus zeamais and Aspergillus chevalieri on the oxygen level in maize stored hermetically. J. Stored Products Res., 36, 25-36.

Person, Jr N.K.; Sorenson, Jr J.W. (1973), Use of gaseous nitrogen for controlling stored-product insects in grains. Cereal Chem., 27, 679-686.

Rehman, Z.U.; Habib, F.; Zafar, S.I. (2002), Nutritional changes in maize (Zea mays) during storage at three temperatures. Food Chem., 77, 1.97-201.

Saltveit, M.E. (2003), Is it possible to find an optimal controlled atmosphere? Postharvest Biol. Tec., 27, 313.
SAS. (1992), Statistical Analysis System, v. 6.08. The SAS Institute, Cary, N. C.

Shunmugam, G.; Jayas, D.S.; White, N.D.G.; Muir, W.E. (2005), Diffusion of carbon dioxide through grain bulks. J. Stored Products Res., 41, 131-144.

Sivertsvik, M.; Rosnes, J.T.; Bergslien, H. (2002), Modified atmosphere packaging. In: Ohlsson, T.; Bengtsson, N., Minimal processing technologies in the food industry, (CRC Press, Boca Raton), 61-86.

Vásquez-Castro, J.A.; Baptista, G.C.; Gadanha, C.D.J.; Trevizan, L.R.P. (2008), Effect of spray volume on the moisture of stored corn and wheat grains. Braz. arch. biol. technol., 51, 3, 453-456.

Received: January 08, 2009; Revised: October 05, 2009; Accepted: August18, 2010 